\title{
IMPLEMENTASI MANAJEMEN PENDIDIKAN KARAKTER DI SEKOLAH
}

\author{
Mujahidatun Mukhlisoh ${ }^{1}$, Suwarno ${ }^{2}$ \\ UIN Syarif Hidayatulloh Jakarta ${ }^{1}$, STAIN Gajah Putih Takengon Aceh Tengah ${ }^{2}$ \\ Email: jidaalmajida@yahoo.com', suwarno0963@yahoo.com²
}

\begin{abstract}
Character is a matter that needs attention in the world of education. Character is a system that underlies a person's thoughts and behavior. So, it can be said that without a strong foundation of character values will make education and the fragility of the young generation of a nation low. In general, this study aims to find and disclose planning, implementation, organizing, evaluating, constraints and solutions in overcoming the constraints of character education implementation. The research method used in this study is a qualitative research design with multi cases of research conducted at two institutions, namely at SDI Raudlatul Jannah Sidoarjo and SD Al-Hikmah Surabaya in a management review with the characteristics of different research objects. The results of the study found SDI Raudlatul Jannah Sidoarjo and Al-Hikmah Elementary School Surabaya, both of them together form a character education program by carrying out stages of management functions effectively. The effectiveness of the planning is evident from the stages of the planning process carried out by the school by preparing a strategic plan for character education
\end{abstract}

Keywords: Implementation, Management, Education, Character

\begin{abstract}
Abstak
Karakter merupakan hal yang perlu diperhatikan dalam dunia pendidikan. Karakter merupakan sistem yang melandasi pemikiran dan perilaku seseorang. Sehingga, bisa dikatakan bahwa, tanpa adanya pondasi nilai-nilai karakter yang kuat akan menjadikan rendahnya pendidikan dan rapuhnya generasi muda suatu bangsa. Secara umum, penelitian ini betujuan untuk menemukan dan mengungkapkan tentang perencanaan, pelaksanaan, pengorganisasian, evaluasi, kendala dan solusi dalam mengatasi kendala implementasi pendidikan karakter.metode penelitian yang digunakan dalam Penelitian ini adalah penelitian kualitatif dengan rancangan multikasus riset dilakukan di dua lembaga yaitu di SDI Raudlatul Jannah Sidoarjo dan SD Al-Hikmah Surabaya dalam tinjauan manajemen dengan karakteristik objek penelitian yang berbeda. Hasil penelitian menemukan SDI Raudlatul Jannah Sidoarjo dan SD Al-Hikmah Surabaya, keduanya sama-sama menyusun program pendidikan karakter dengan melakukan tahapan fungsi manajemen secara efektif. Keefektifan perencanaan tersebut terbukti dari adanya tahapan proses perencanaan yang dilakukan oleh sekolah dengan cara menyusun rencana strategis pendidikan karakter.
\end{abstract}

Kata Kunci: Implementasi, Manajemen, Pendidikan, Karakter 


\section{A. Pendahuluan}

Pendidikan karakter merupakan hal yang perlu diperhatikan dalam dunia pendidikan. Sebab, karakter merupakan sistem yang melandasi pemikiran dan perilaku seseorang. Hal ini sesuai dengan ungkapan Simon Philips dalam Muslich bahwa "karakter merupakan kumpulan tata nilai yang menuju pada suatu sistem, yang melandasi pemikiran, sikap, dan perilaku yang ditampilkan” (Muslich, 2011:70). Sehingga, bisa dikatakan bahwa, tanpa adanya pondasi nilai-nilai karakter yang kuat akan menjadikan rendahnyapendidikan dan rapuhnya generasi muda suatu bangsa.

Beberapa fakta rendahnya karakter suatu bangsa tercermin pada peserta didik, diantaranya adalah rendahnya kejujuran siswa yang dibuktikan dengan adanya budaya cheating pada saat ujian, rendahnya adab atau etika dalam bersikap dan rasa hormat kepada orang tua dan guru,kurangnya etika dalam menggunakan bahasa yang sopan dan santun dan tingginya kasus perkelahian dan kriminal yang dilakukan peserta didik pada tingkat satuan pendidikan dasar dan menengah.Beberapa fenomena tersebut sesuai dengan hasil penelitian yang dilakukan oleh Asep Saipul Hidayat di Dinas Pendidikan Kabupaten Garut pada tahun 2012 (Hidayat, 2012:72).

Fenomena lain yang menunjukkan rendahnya karakter peserta didik adalah pergaulan bebas. Sebagaimana hasil survei BNN Tahun 2017 menyebutkan bahwa, para pelajar atau mahasiswa yang pernah melakukan pergaulan bebas di Provinsi Sulawesi utara sebanyak 13\%, Papua Barat, NTT, Kalimantan Utara dan Bali sebanyak 9\% dan Provinsi Sumatera Barat sebanyak 3\%). Data tertinggi terdapat pada Provinsi Sulawesi Utara dan Papua Barat.

Jika dilihat dari beberapa fakta yang telah disebutkan di atas, maka beberapa masalah tersebut merupakan masalah yang berpotensi menghancurkan masa depan generasi muda. Sebab, beberapa pelaku masalah di atas adalah para pelajar. Hal ini bertolak belakang dari tujuan adanya pendidikan yang tertera dalam UUSPN Nomor 20 Tahun 2003 Pasal 3 Tentang Tujuan Pendidikan, yakni: "Pendidikan nasional berfungsi mengembangkan kemampuan dan membentuk watak serta peran bangsa yang bermartabat dalam rangka mencerdaskan kehidupan bangsa, bertujuan untuk berkembangnya potensi peserta didik agar 
menjadi manusia yang beriman dan bertaqwa kepada Tuhan Yang Maha Esa, yang berakhlak mulia, sehat, berilmu, cakap, kreatif, mandiri dan menjadi warga Negara yang demokratis serta bertanggungjawab".

Belakangan ini, pemerintah telah mencoba mengimplementasikan pendidikan karakter di institusi pendidikan, mulai dari PAUD, SD/MI, SMA/MA dan Perguruan Tinggi. Ada beberapa hal yang menjadi dasar atau alasan pentingnya pembangunan karakter, baik secara filosofis, ideology, normatif, historis maupun sosiokultural. Namun yang menjadi permasalahan sampai saat ini adalah dalam hal manajemen pendidikan karakter di sekolah. Karena pendidikan karakter bukan mata pelajaran tetapi harus diimplementasikan oleh pihak sekolah. Tujuan dari manajemen pendidikan karakter di sekolah, adalah tercapainya tujuan pendidikan karakter di sekolah yang efektif dan efisien. Melalui ketercapaian tujuan pendidikan karakter di sekolah, diharapkan terlahir generasi muda masa depan, khususnya peserta didik yang tidak saja cerdas secara psikomotorik, tetapi juga memiliki keluhuran karakter. Mereka merupakan sosok manusia unggul yang dibalut dengan ketinggian dan keluhuran karakter.

Berdasarkan pengamatan sementara di lapangan, peneliti menemukan adanya proses pengembangan nilai-nilai karakter di SDI Raudlatul Jannah Sidoarjo dan SD Al-Hikmah Surabaya. Adanya implementasi pendidikan karakter di SDI Raudlatul Jannah Sidoarjo dan SD Al-Hikmah Surabaya menjadikan keduanya sebagai sekolah terbaik di kotanya. Keberhasilan penanaman pendidikan karakter di SDI Raudlatul Jannah Sidoarjo dan SD Al-Hikmah Surabaya tentunya berangkat dari bagusnya manajemen pendidikan karakter yang diterapkan di kedua sekolah tersebut. Sebab, dalam pendidikan karakter di sekolah atau madrasah, semua stakeholder harus dilibatkan, baik kurikulum, proses pembelajaran, pengelolaan mata pelajaran, pembiayaan, sarana prasarana, etos kerja guru dan tenaga kependidikan, maupun lingkungan sekolah. Dari latar belakang tersebut di atas maka konteks dari penelitian ini adalah manajemen pendidikan karakter di Sekolah, dengan rumusan masalah penelitian ini adalah sebagai berikut: 1) Bagaimana perencanaan pendidikan karakter di SDI Raudlatul Jannah Sidoarjo dan di SDI Al-Hikmah Surabaya? 2) Bagaimana pengorganisasian pendidikan karakter di SDI Raudlatul Jannah Sidoarjo dan di 
SDI Al-Hikmah Surabaya?. 3) Bagaimana pelaksanaan pendidikan karakter di SDI Raudlatul Jannah Sidoarjo dan di SDI Al-Hikmah Surabaya?. 4) Bagaimana evaluasi atau controlling pendidikan karakter di SDI Raudlatul Jannah Sidoarjo dan di SDI Al-Hikmah Surabaya?

\section{B. Landasan Teori}

\section{Tinjauan Tentang Manajemen}

Menurut George. R Terry manajemen adalah suatu proses khas yang terdiri atas tindakan-tindakan perencanaan, pengorganisasian, penggerakan, dan pengendalian untuk menentukan serta mencapai tujuan melalui pemanfaatan SDM dan sumber daya lainnya (Athoillah, 2010:16). Sedangkan menurut Hanry L. Sisk mendefinisikan Management is the coordination of all resources throughthe processes of planning, organizing, directing and controlling in order to attain sted objectivies. Artinya manajemen adalah pengkoordinasian untuk semua sumber-sumber melalui proses-proses perencanaan, pengorganisasian, pelaksanaan dan pengawasan di dalam mencapai tujuan (Sisk, 1969:6)

Berdasarkan pernyataan di atas, maka manajemen diartikan sebagai sebuah pedoman dalam mencapai tujuan. Manajemen memberikan arahan dalam merencanakan, melaksanakan dan mengevaluasi atau mengawasi sebuah proses atau tindakan dalam mencapai tujuan. Dalam proses pengawasan, manajemen membantu memilah apakah proses tersebut mampu dilaksanakan sesuai dengan rencana atau perlu diperbaiki.

\section{Tinjaun Tentang Pendidikan Karakter}

Terminologi pendidikan karakter telah dikenal sekitar tahun 1900. Istilah pendidikan karakter dipelopori oleh Thomas Lickona dalam buku "Education for Character". Menurutnya, pendidikan karakter mengandung tiga aspek utama, yaitu mengetahui kebaikan, mencintai kebaikan dan melakukan kebaikan (Lickona, 2015:595). Ungkapan di atas diperjelas oleh Dalmetri (2014:271) dalam jurnal Al-Ulum Universitas Indraprasta PGRI Jakarta, bahwa, pendidikan karakter bukan hanya menjelaskan tentang mana yang benar dan mana yang salah, akan tetapi menanamkan kebiasaan kepada peserta didik hingga peserta didik mengerti, dan mampu menerapkannya. 
Tinjauan Tentang Implementasi Pendidikan Karakter di Sekolah dalam Lingkup Manajemen

Berdasarkan pengertian-pengertian yang sudah dijelaskan sebelumnya tentang manajemen dan manajemen pendidikan, maka dapat disimpulkan bahwa, manajemen pendidikan karakter merupakan tata cara pengelolaan membentuk karakter dan mengembangkan kepribadian melalui keteladanan, penanaman kedisiplinan, pembiasaan dan menciptakan suasana yang kondusif, serta integrasi, dan internalisasi. Jika dilihat dari segi manajemen, maka manajemen mempunyai beberapa fungsi manajemen yaitu perencanaan, pengorganisasian, pelaksanaan dan evaluasi. Hal ini berlaku juga dalam manajemen pendidikan karakter di sekolah. Pertama Perencanaan Pendidikan Karakter, Langkah awal dalam perencanaan pendidikan karakter adalah mendesain kurikulum dengan pendidikan karakter. Artinya, kurikulum yang dirancang harus memuat grand design pendidikan karakter, baik berupa formal maupun hidden curriculum.

Kedua Pengorganisasian Pendidikan Karakter, Pengorganisasian atau pengelolaan pendidikan karakter merupakan proses mengkoordinasikan sumber daya manusia dalam menerapkan pendidikan karakter. Sehingga, komponenkomponen dalam pengorganisasian adalah sumber daya manusia (SDM) yang megatur dan mengurus penyelenggaraan sekolah, pengelolaan dalam memimpin, membina, mengkoordinasikan serta mengurus sekolah dalam menciptakan budaya berkarakter. Jika disebutkan secara langsung maka, komponen-komponen tersebut adalah kepala sekolah, staff TU, OB, pustakawan, guru dan siswa.

Ketiga, Pelaksanaan Pendidikan Karakter, Pelaksanaan merupakan kegiatan untuk merealisasikan rencana menjadi tindakan nyata dalam mewujudkan tujuan secara efektif dan efisien. Pelaksanaan pendidikan karakter merupakan kegiatan inti dari pendidikan karakter. Keempat, Pengawasan Pendidikan Karakter, Pengawasan adalah cara sebuah lembaga mewujudkan kinerja dan mutu yang efektif dan efisien untuk mendukung terwujudnya visi misi lembaga atau organisasi (Fahmi, 2014:84).

\section{Penelitian terdahulu yang relevan}

Penelitian ini ada kemiripan dengan penelitian sebelumnya, dari sisi pendidikan karakternya Beberapa penelitian sebelumnya Manajemen Asrama 
Sekolah Berbasis Karakter ataupun manajemen pendidikan; beberapa penelitian terdahulu yang serupa dengan penelitian ini antara lain adalah: Studi kasus di MA Darul Ulum Probolinggo, Penelitian Sujarwo membahas tentang manajemen asrama berbasis pendidikan karakter dengan metode penelitian kualitatif. Hasil penelitian ini adalah (1) penyusunan program kerja asrama sekolah dilakukan dengan melakukan penataan, yaitu perumusan visi misi, menetapkan tujuan dan sasaran, melakukan analisis strategis dan target, (2) pengorganisasian pengelolaan asrama sekolah yaitu langkah-langkah departementalisasi, pembagian kerja dan pembagian santri. Ruang lingkup pengorganisasian santri diantaranya adalah pembagian kelompok santri dan penempatan santri pada unit-unit kamar, (3) peningkatan kinerja asrama sekolah, yaitu dengan memberikan motivasi, melakukan komunikasi, baik formal maupun non-formal, kepemimpinan kolektif, (4) pengawasan dilakukan dengan cara penempatan standar akademik dan non akademik, pemantauan dan penilaian santri. Perbedaan penelitian Sujarwo dengan penelitian ini adalah, pada penelitian ini membahas tentang manajemen pendidikan karakter di sekolah dengan fokus bahasan konsep dasar, kendala dan solusi pelaksanaan manajemen pendidikan karakter di SDI Raudlatul Jannah Sidoarjo dan SD Al-Hikmah Surabaya, sedangkan pada penelitian Imam Sujarwo membahas tentang manajemen pendidikan karakter di asrama. Sedangkan, persamaan dari penelitian ini dengan penelitian Imam Sujarwo adalah bersifat kualitatif dan sama-sama membahas manajemen pendidikan karakter. Persamaannya dengan penelitian ini adalah Sama-sama membahas tentang pendidikan karakter dan menggunakan metode penelitian kualitatif.

The Significance of Environmental Contents in Character Education for Quality of Life, Jurnal Internasional Procedia Science Direct tahun 2015, oleh Murty Magda Pane, hasil penelitian menunjukan Lingkungan berpengaruh signifikan terhadap karakter peserta didik. Untuk menerapkan pendidikan karakter, maka harus mengintegrasikan pendidikan karakter pada kurikulum sekolah dan lingkungan sekolah. Penelitian ini membahas tentang pengaruh lingkungan terhadap pendidikan karakter dalam meningkatkan kualitas hidup. Penelitian ini menggunakan metode kualitatif dengan teknik wawancara kepada 33 siswa jurusan yang berbeda. Hasil penelitian ini menunjukkan bahwa 91\% 
siswa setuju bahwa lingkungan berpengaruh, sedangkan sisanya $1 \%$ tidak setuju. Perbedaan penelitian ini dengan penelitian Murty Magda Pane adalah, pada penelitian ini membahas tentang implementasi pendidikan karakter dari segi perencanaan, pelaksanaan, pengorganisasian, evaluasi, kendala dan solusinya. Sedangkan, pada penelitian Murty Magda Pane membahas tentang pengaruh lingkungan terhadap pendidikan karakter dalam meningkatkan kualitas hidup. Persamaan dengan penelitian ini Sama-sama membahas tentang pendidikan karakter dan menggunakan metode penelitian kualitatif.

\section{Metode Penelitian}

\section{Pendekatan dan Jenis Penelitian}

Penelitian ini merupakan penelitian kualitatif dengan rancangan multikasus. Alasan peneliti menggunakan metode kualitatif adalah, karena peneliti akan meneliti tentang masalah atau fenomena dengan gambaran yang lengkap untuk mendapatkan pemahaman yang mendalam sehingga menghasilkan sebuah teori. Penelitian ini dilakukan pada peristiwa yang sedang terjadi, bukan peristiwa yang lampau (ex post facto). Menurut Haryono (2008:60), ada enam ciri penelitian kualitatif, yaitu (a) concern of context (b) natural setting (c) human instrument (d) descriptive data (e) emergent design dan (f) inductive analysis. Oleh karena itu, pada penelitian ini, peneliti bersikap selektif, sungguh-sungguh dan berhati-hati dalam menyaring data, sehingga mendapatkan data yang relevan.

\section{Sumber Data}

Sumber data pada penelitian ini terbagi menjadi dua, yaitu:

Data Primer: data primer pada penelitian ini berupa data yang didapat dari kepala sekolah, guru, waka kurikulum dan wali murid SDI Raudlatul Jannah Sidoarjo dan SD Al-Hikmah Surabaya, meliputi dokumen profil sekolah, dokumen kurikulum sekolah, dokumen rapor pendidikan karakter sekolah dan lain sebagainya.

Data Sekunder: Data sekunder pada penelitian ini diperoleh dari studi pustaka yang bertujuan untuk memperoleh landasan teori yang bersumber dari beberapa buku, laporan-laporan penelitian terdahulu dan sumber lain yang berhubungan dengan penelitian ini, yaitu tentang implementasi pendidikan 
karakter. Menurut Moleong (2000:158), data sekunder berupa gambar, foto dan catatan yang berhubungan dengan penelitian.

\section{Teknik Pengumpulan Data}

Observasi yang dilakukan peneliti dalam penelitian ini adalah observasi peran serta (participant observation). Peneliti memperhatikan dan mengamati secara langsung kegiatan di SDI Raudlatul Jannah Sidoarjo dan SD Al-Hikmah Surabaya untuk mendapatkan data tentang implementasi pendidikan karakter di SDI Raudlatul Jannah Sidoarjo dan SD Al-Hikmah Surabaya. Observasi pada penelitian ini mengacu pada teori Arikunto dengan membagi menjadi tiga tahapan, yaitu descriptive observations, focused observations dan selective observations (Arikunto, 2002:131).

Studi dokumentasi dalam penelitian ini untuk melengkapi data tentang manajemen pendidikan karakter, profil sekolah dan nilai-nilai karakter sekolah dalam proses observasi dan wawancara berupa gambar, dokumen tertulis dan rekaman. Hal ini sesuai dengan pendapat Arikunto (2002:136), bahwa, dokumen bisa berupa gambar, usulan, buku tahunan, karangan dan selebaran berita.

Wawancara dalam penelitian ini bebas terpimpin dan diajukan kepada kepala sekolah, waka kurikulum, guru dan wali murid untuk mendapatkan informasi seputar implementasi pendidikan karakter. Menurut Arikunto, wawancara juga

\section{Teknik Analisis Data}

Analisis data dalam penelitian ini menggunakan teknik analisis data dalam situs yang dikembangkan oleh Miles and Huberman. Data yang sudah terkumpul dibuat dalam matriks. Dalam matriks akan disajikan penggalan-penggalan data deskriptif sekitar peristiwa atau pengalaman tertentu yang menyekat data sebelum dan sesudahnya. Setelah data dimasukkan kedalam matriks selanjutnya di buat daftar cek (Miles and Huberman, 2007:139-140). Analisis data dalam penelitian kualitatif dilakukan sejak sebelum memasuki lapangan, selama memasuki lapangan, dan setelah selesai dari lapangan. Nasution dalam Sugiyono (2008:236), menyatakan bahwa analisis data telah dimulai sejak merumuskan dan menjelaskan masalah, sebelum terjun ke lapangan, dan berlangsung terus sampai penulisan hasil penelitian. Miles and Huberman dalam Sugiyono (2008:237), 
mengemukakan aktivitas dalam analisis data kualitatif harus dilakukan secara terus menerus sampai tuntas, sehingga datanya sudah jenuh. Analisis data dalam penelitian ini dilaksanakan pada saat pengumpulan data dalam periode tertentu. Pada saat wawancara, peneliti sudah melakukan analisis terhadap jawaban yang diwawancarai. Apabila jawaban yang disampaikan oleh orang yang diwawancarai atau informan setelah dianalisis dirasa kurang memuaskan, maka peneliti melanjutkan pertanyaan lagi, sampai tahap tertentu sehingga diperoleh data atau informasi yang lebih kredibel.

Untuk menyajikan data agar mudah dipahami, maka langkah-langkah anlisis data yang digunakan dalam penelitian ini adalah Analysis Interactive Model dari Miles dan Huberman, yang membagi langkah-langkah dalam kegiatan analisis data dengan beberapa bagian yaitu pengumpulan data (data collection), reduksi data (data reduction), penyajian data (data display), dan kesimpulan atau verifikasi. Pertama, Pengumpulan Data. Pada tahap ini peneliti mengumpulkan data yang sesuai dengan fokus penelitian dengan cara observasi, wawancara dan dokumentasi. Setelah itu diedit dan dipilah-pilah. Kemudian dianalisis secara deskriptif.

Kedua, Reduksi Data. Pada tahap ini peneliti menyeleksi, menyederhanakan dan merangkum data yang didapatkan dari lapangan dan disusun secara sistematis dalam bentuk uraian dan laporan agar mudah difahami. Ketiga Penyajian Data, Pada tahap ini, peneliti manyajikan data yang sudah direduksi berbentuk uraian singkat, bagan dan diskripsi yang menyeluruh pada aspek yang diteliti. Keempat, Simpulan atau Verifikasi. Pada tahapan ini, peneliti menyimpulkan data yang telah diperoleh dan bersifat sementara. Karna, data tersebut akan berubah apabila peneliti menemukan data lain yang lebih kuat. Pada tahap ini, peneliti juga mencari makna data yang telah terkumpul dengan mencari pola, tema hubungan, persamaan atau hipotesis dari hasil data di lapangan.

\section{Hasil}

Temuan hasil penelitian yang sesuai dengan fokus penelitian, yaitu tentang: (a) perencanaan pendidikan karakter di SDI Raudlatul Jannah Sidoarjo dan SD Al-Hikmah Surabaya (b) pengorganisasian pendidikan karakter di SDI 
Raudlatul Jannah Sidoarjo dan SD Al-Hikmah Surabaya (c) pelaksanaan pendidikan karakter di SDI Raudlatul Jannah Sidoarjo dan SD Al-Hikmah Surabaya (d) evaluasi pendidikan karakter di SDI Raudlatul Jannah Sidoarjo dan SD Al-Hikmah Surabaya

Perencanaan Pendidikan Karakter di SDI Raudlatul Jannah Sidoarjo dan SD Al-Hikmah Surabaya

Perencanaan pendidikan karakter di SDI Raudlatul Jannah Sidoarjo dan SD Al-Hikmah Surabaya melibatkan seluruh elemen sekolah, baik kepala sekolah, guru kelas, guru mata pelajaran dan guru BK, bahkan petugas kebersihan sekolah. Untuk lebih jelasnya, seperti tabel di bawah ini:

Tabel 1

Perencanaan Pendidikan Karakter di SDI Raudlatul Jannah Sidoarjo dan SD Al-Hikmah Surabaya

\begin{tabular}{|c|c|c|}
\hline $\begin{array}{c}\text { Fungsi } \\
\text { Manajemen }\end{array}$ & SDI Raudlatul Jannah Sidoarjo & $\begin{array}{l}\text { SD Al-Hikmah } \\
\text { Surabaya }\end{array}$ \\
\hline Perencanaan & $\begin{array}{l}\text { 1. Mengadakan rapat yayasan dengan } \\
\text { kepala sekolah dan tim manajemen. } \\
\text { Rapat ini dilakukan setiap satu bulan } \\
\text { sekali. Dalam rapat ini membahas } \\
\text { tentang nilai-nilai karakter, indikator } \\
\text { dan sub indikator beserta penyampaian } \\
\text { kendala dalam kegiatan sebelumnya. } \\
\text { Selain iru, rapat ini dilakukan oleh } \\
\text { pengurus yayasan pada awal tahun } \\
\text { ajaran baru guna merancang kegiatan } \\
\text { satu tahun ke depan, kelengkapan } \\
\text { fasilitas, anggaran dan kendala serta } \\
\text { solusi (dokumen hasil rapat yayasan dan } \\
\text { kepala sekolah tahun } 2017 \text { ) } \\
\text { 2. Mengadakan rapat lanjutan antara } \\
\text { kepala sekolah dan tim manajemen } \\
\text { kurikulum sekolah. rapat ini dilakukan } \\
\text { setiap } 2 \text { Minggu sekali. Rapat ini berisi } \\
\text { kegiatan yang akan dilakukan dalam } \\
\text { mengimplementasikan pendidikan } \\
\text { karakter (dokumen hasil rapat kepala } \\
\text { sekolah dengan tim manajemen } \\
\text { kurikulum tahun 2017) } \\
\text { 3. Mengadakan rapat lanjutan dalam } \\
\text { lingkup kecil. Rapat ini dihadiri oleh } \\
\text { waka kurikulum dan koordinator } \\
\text { masing-masing jenjang. Rapat ini } \\
\text { dilakukan setiap satu Minggu sekali. } \\
\text { Rapat ini berisi tentang penyampaian } \\
\text { langkah lanjutan dan hasil evaluasi } \\
\text { kegiatan sebelumnya }\end{array}$ & $\begin{array}{l}\text { 1. Kepala sekolah } \\
\text { melakukan rapat kerja } \\
\text { secara menyeluruh } \\
\text { dengan wakil, kepala } \\
\text { unit, koordinator circle, } \\
\text { guru, staff, dan } \\
\text { karyawan pada awal } \\
\text { ajaran baru. Pada rapat } \\
\text { ini membahas tentang } \\
\text { jenis kegiatan, tujuan } \\
\text { pelaksanaan, sasaran } \\
\text { kegiatan dan nilai } \\
\text { karakter yang akan } \\
\text { dimunculkan dalam } \\
\text { kegiatan tersebut. } \\
\text { Selain itu, membahas } \\
\text { berapa budgeting untuk } \\
\text { kegiatan tersebut (hasil } \\
\text { rapat awal tahun, tahun } \\
\text { 2017) } \\
\text { 2. Koordinasi antar circle. } \\
\text { Koordinasi ini } \\
\text { menindaklanjuti hasil } \\
\text { rapat akbar. Koordinasi } \\
\text { antar circle di SD Al- } \\
\text { Hikmah terbagi } \\
\text { menjadi } 3 \text { Yaitu circle }\end{array}$ \\
\hline
\end{tabular}

Jurnal Darussalam; Jurnal Pendidikan, Komunikasi dan Pemikiran Hukum Islam Vol. XI, No 1:56-75. September 2019. ISSN: 1978-4767 (Cetak), ISSN: 2549-4171(Online) Terakreditasi Nasional. SK. No.21/E/KPT/2018 
Lanjutan Tabel 1

\begin{tabular}{|l|l|l|}
\hline $\begin{array}{c}\text { Fungsi } \\
\text { Manajemen }\end{array}$ & SDI Raudlatul Jannah Sidoarjo & SD Al-Hikmah Surabaya \\
\hline & $\begin{array}{l}\text { (dokumen hasil rapat rutin tahun } \\
\text { 2017) }\end{array}$ & $\begin{array}{l}\text { (kepala sekolah, wakil } \\
\text { dan kepala unit), circle 2 } \\
\text { (koordinator jenjang) dan }\end{array}$ \\
4engadakan rapat antara koordinator \\
jenjang dan guru di masing-masing \\
jenjang. Rapat ini dilakukan setiap hari \\
pada saat jam pelajaran tilawati atau \\
pembelajaran al-Qur'an. Rapat ini \\
(Dokumen Renstra SD Al- \\
berisi tentang kegiatan lanjutan dalam \\
implementasi pendidikan karakter \\
beserta purabaya tahun \\
pendidikan karakter yang dialami oleh \\
guru saat di kelas (Dokumen hasil \\
rapat coordinator jenjang tahun 2017)
\end{tabular}

Sumber: Hasil observasi di SDI Roudlatul Jannah Sidoarjo 25 Agustus 2017 dan SD Alhikmah Surabaya 15 September 2017.

\section{Pengorganisasian Pendidikan Karakter di SDI Raudlatul Jannah Sidoarjo dan SD Al-Hikmah Surabaya}

Pengorganisasian pendidikan karakter di SDI Raudlatul jannah Sidoarjo dan SD Al-Hikmah Surabaya dilakukan dengan cara mengkoordinasikan seluruh warga sekolah, yaitu kepala sekolah, waka kurikulum, guru kelas, guru mata pelajaran, BK, siswa bahkan cleaning service dalam mencapai tujuan pendidikan karakter. Lebih jelasnya, hasil penelitian peneliti terkait pengorganisasian pendidikan karakter di SDI Raudlatul Jannah Sidoarjo dan SD Al-Hikmah Surabaya disajikan dalam tabel di bawah ini:

Tabel 2

Pengorganisasian Pendidikan Karakter di SDI Raudlatul Jannah Sidoarjo dan SD Al-Hikmah Surabaya.

\begin{tabular}{|c|c|c|}
\hline $\begin{array}{c}\text { Fungsi } \\
\text { Manajemen }\end{array}$ & SDI Raudlatul Jannah Sidoarjo & SD Al-Hikmah Surabaya \\
\hline Pengorganisasian & $\begin{array}{l}\text { 1. Setiap satu tahun sekali, kepala } \\
\text { sekolah beserta tim manajemen } \\
\text { sekolah akan memilih beberapa } \\
\text { guru untuk menjadi tim } \\
\text { manajemen kurikulum } \\
\text { pendidikan karakter. Pemilihan } \\
\text { tersebut dilihat dari hasil } \\
\text { penilaian supervisi guru yang } \\
\text { dilakukan setiap 1 semester } \\
\text { sekali dan lamanya pengabdian. } \\
\text { Syarat khusus menjadi tim } \\
\text { manajemen nilai }\end{array}$ & $\begin{array}{l}\text { 1. Pembagian tugas pada } \\
\text { masing-masing circle } \\
\text { (dokumen pembagian } \\
\text { tugas tim tahun 2017) } \\
\text { 2. Pembagian tugas pada tim } \\
\text { manajemen kurikulum } \\
\text { (dokumen pembagian } \\
\text { tugas tim manajemen } \\
\text { kurikulum tahun 2017) } \\
\text { 3. Pemilihan penanggung } \\
\text { jawab tugas. (dokumen } \\
\text { hasil rapat dan SK }\end{array}$ \\
\hline
\end{tabular}


Lanjutan Tabel 2

\begin{tabular}{|c|c|c|}
\hline $\begin{array}{c}\text { Fungsi } \\
\text { Manajemen }\end{array}$ & SDI Raudlatul Jannah Sidoarjo & SD Al-Hikmah Surabaya \\
\hline & $\begin{array}{l}\text { karakter adalah, mereka salah } \\
\text { satu dari koordinator jenjang } \\
\text { pada tahun sebelumna } \\
\text { (dokumen hasil rapat } \\
\text { pembentukan tim manajemn } \\
\text { kurikulum dan sk } \\
\text { pengangkatan oleh kepala } \\
\text { sekolah tahun 2017). } \\
\text { 2. Selain itu, kepala sekolah juga } \\
\text { akan memilih koordinator } \\
\text { masing-masing jenjang. } \\
\text { Pemilihan koordinator jenjang } \\
\text { serupa dengan pemilihan tim } \\
\text { manajemen kurikulum } \\
\text { (Dokumen SK penugasan oleh } \\
\text { kepala sekolah tahun 2017), } \\
\text { 3. Pemilihan tim TPDS. } \\
\text { Pemilihan ini dilakukan } \\
\text { dengan cara pemilu atau voting } \\
\text { suara terbanyak (dokumen } \\
\text { hasil pemilihan TPDS tahun } \\
\text { 2017) }\end{array}$ & $\begin{array}{l}\text { 4. pengangkatan oleh kepala } \\
\text { sekolah tahun 2017) } \\
\text { Pembagian tugas ini dilakukan } \\
\text { pada saat rapat besar awal } \\
\text { tahun ajaran baru. Sehingga, } \\
\text { pada saat pelaksanaan, } \\
\text { masing-masing program kerja } \\
\text { sudah mempunyai } \\
\text { penanggung jawab masing- } \\
\text { masing (dokumen rapat } \\
\text { pembagian tugas tahun 2017) }\end{array}$ \\
\hline
\end{tabular}

Sumber: Hasil observasi di SDI Roudlatul Jannah Sidoarjo 25 Agustus 2017, dan SD Alhikmah Surabaya 15 September 2017

\section{Pelaksanaan Pendidikan Karakter di SDI Raudlatul Jannah Sidoarjo dan SD}

\section{Al-Hikmah Surabaya}

Hasil penelitian menunjukan bahwa, pelaksanaan pendidikan karakter di SDI Raudlatul Jannah Sidoarjo dan SD Al-HIkmah Surabaya dengan melakukan pendekatan keteladanan (uswatunhasanah) dan pendekatan sistem. Sebagaimana ditunjukan dalam tabel berikut;

Tabel 3

Pelaksanaan Pendidikan Karakter di SDI Raudlatul Jannah Sidoarjo dan SD Al-Hikmah Surabaya.

\begin{tabular}{|c|c|c|}
\hline $\begin{array}{c}\text { Fungsi } \\
\text { Manajemen }\end{array}$ & SDI Raudlatul Jannah Sidoarjo & SD Al-Hikmah Surabaya \\
\hline Pelaksanaan & $\begin{array}{l}\text { 1. Terintegrasi dalam mata pelajaran, } \\
\text { proses KBM, administrasi } \\
\text { pembelajaran dan kegiatan harian di } \\
\text { sekolah (Dokumen RPP berbasis } \\
\text { Karakter SDI Roudlatul Jannah } \\
\text { Sidoarjo tahun 2017) } \\
\text { 2. Melakukan kegiatan pembiasaan } \\
\text { atau kegiatan penunjang pendidikan }\end{array}$ & $\begin{array}{l}\text { 1. Diterapkan dalam kegiatan } \\
\text { ekstrakurikuler (jadwal } \\
\text { kegiatan ekstra kurikuler } \\
\text { SD Al Hikmah Surabaya } \\
\text { tahun } 2017 \\
\text { 2. Kegiatan ekstrakurikuler } \\
\text { (melukis, bela diri, } \\
\text { kelompok ilmiah remaja, }\end{array}$ \\
\hline
\end{tabular}


Lanjutan Tabel 3

\begin{tabular}{|c|c|c|}
\hline $\begin{array}{c}\text { Fungsi } \\
\text { Manaiemen }\end{array}$ & SDI Raudlatul Jannah Sidoarjo & SD Al-Hikmah Surabaya \\
\hline & $\begin{array}{l}\text { karakter di lingkungan sekolah dan } \\
\text { di rumah. Meliputi, pembiasaan } \\
\text { sholat berjamaah, sholat duha, } \\
\text { berdoa, berbaris tertib, disiplin, } \\
\text { dsb, (Dokumen kegiatan berbasis } \\
\text { karakter, dan foto kegiatan SDI } \\
\text { Roudlatul Jannah Tahun 2017) } \\
\text { 3. Terwujud dalam kegiatan } \\
\text { ekstrakurikuler (Dokumen jadwal } \\
\text { kegiatan Ekstra kurikuler tahun } \\
\text { SDI Roudlatul Jannah tahun 2017) } \\
\text { 4. Keteladanan sikap guru (Observasi } \\
\text { bulan tanggal 25 Agustus tahun } \\
\text { 2017, kegiatan Jum'at bersih, guru } \\
\text { terlibat langsung di dalamnya) }\end{array}$ & $\begin{array}{l}\text { bimbingan olimpiade sains } \\
\text { dan matematika, dokter } \\
\text { cilik, sepak bola, pramuka, } \\
\text { teater, Al-Hikmah writing } \\
\text { club dan bussines day } \\
\text { (Dokumen foto kegiatan } \\
\text { SD Al-Hikmah Surabaya } \\
\text { tahun 2017) } \\
\text { 3. Kegiatan khas Al-Hikmah, } \\
\text { yaitu menerapkan dalam } \\
\text { kegiatan pembiasaan, } \\
\text { diantaranya adalah } \\
\text { menerapkan adab salam, } \\
\text { ibadah praktis, berdoa } \\
\text { sebelum memulai } \\
\text { pembelajaran dengan cara } \\
\text { menunjuk siswa memimpin } \\
\text { berdoa, siroh nabawiyah, } \\
\text { menjaga kebsihan } \\
\text { lingkungan, literasi } \\
\text { (Observasi pada tanggal } 15 \\
\text { September tahun } 2015) \\
\text { 4. Keteladanan guru dan } \\
\text { tenaga kependidikan di } \\
\text { sekolah, meliputi guru } \\
\text { diwajibkan datang lebih } \\
\text { awal daripada siswa, sopan } \\
\text { dalam perbuatan dan } \\
\text { perkataan (Observasi } \\
\text { tanggal 15 September } \\
\text { 2017, semua guru } \\
\text { melakukan penyambutan } \\
\text { terhadap siswa) }\end{array}$ \\
\hline
\end{tabular}

Sumber: Hasil observasi di SDI Roudlatul Jannah Sidoarjo 25 Agustus 2017, dan SD Alhikmah Surabaya 15 September 2017

\section{Controlling/Evaluasi Pendidikan Karakter di SDI Raudlatul Jannah}

\section{Sidoarjo dan SD Al-Hikmah Surabaya}

Hasil penelitian menunjukan bahwa, evaluasi pendidikan karakter di SDI Raudlatul Jannah Sidoarjo dan SD Al-Hikmah Surabaya mencakup dua aspek, yaitu proses dan hasil. Seperti pada tabel berikut: 


\section{Tabel 4}

Evaluasi Pendidikan Karakter di SDI Raudlatul jannah Sidoarjo dan SD Al-Hikmah Surabaya,

\begin{tabular}{|c|c|c|}
\hline $\begin{array}{c}\text { Fungsi } \\
\text { manajemen }\end{array}$ & $\begin{array}{c}\text { SDI Raudlatul Jannah } \\
\text { Sidoarjo }\end{array}$ & SD Al-Hikmah Surabaya \\
\hline Evaluasi & $\begin{array}{l}\text { 1. Evaluasi dilakukan dengan } \\
\text { pemantauan sikap siswa } \\
\text { saat di sekolah oleh guru } \\
\text { kelas dan BK melalui tata } \\
\text { tertib sekolah (Dokumen } \\
\text { panduan akademis sekolah } \\
\text { SDI Roudlatul Jannah } \\
\text { tahun 2017) } \\
\text { 2. Evaluasi didapat dari buku } \\
\text { penilaian pembiasaan siswa } \\
\text { baik di rumah maupun di } \\
\text { sekolah yang dibuktikan } \\
\text { dengan adanya rapor } \\
\text { karakter siswa (dokumen } \\
\text { buku rapot karakter tahun } \\
\text { 2017) didapatkan dari } \\
\text { 3. Evaluasi dist sebagai } \\
\text { kegiatan home visit siswa } \\
\text { penilaian karakter siang } \\
\text { saat di rumah yang } \\
\text { melibatkan orangtua } \\
\text { (jadwal home visit tahun } \\
\text { 2017) } \\
\text { Evaluasi dilakukan dengan } \\
\text { mengadakan koordinasi } \\
\text { antara koordinator jenjang, } \\
\text { guru jenjang dan kepala } \\
\text { sekolah serta yayasan. } \\
\text { Evaluasi ini dilakukan } \\
\text { untuk mengetahui seberapa } \\
\text { besar tingkat keberhasilan } \\
\text { pendidikan karakter dan } \\
\text { siapa saja yang kurang } \\
\text { dalam pelaksanaan } \\
\text { pendidikan harakter } \\
\text { (dokumen hasil rata } \\
\text { koordinasi tahun 2017) }\end{array}$ & $\begin{array}{l}\text { Evaluasi dilakukan dengan dua } \\
\text { tahap, yaitu: } \\
\text { 1. Evaluasi formal } \\
\text { Meliputi, kegiatan rapat rutin } \\
\text { yang dilaksanakan oleh masing- } \\
\text { masing circle. Circle } 1 \text { (kepala } \\
\text { sekolah dan wakil kepala } \\
\text { sekolah) circle } 2 \text { (koordinator } \\
\text { jenjang dan kepala unit) circle } 3 \\
\text { (guru). Rapat dilakukan setiap } \\
\text { satu bulan sekali. Selain itu, } \\
\text { circle } 3 \text { mempunyai jadwal } \\
\text { evaluasi setiap minggu yang } \\
\text { dinamakan dengan KKG } \\
\text { (dokumen hasil rapat tahun } 2017 \text { ) } \\
\text { 2. Evaluasi non formal berupa (a) } \\
\text { catatan lapangan yang dimiliki } \\
\text { oleh masing-msing guru dengan } \\
\text { format yang berbeda-beda. } \\
\text { Catatan ini bersifat pribadi. } \\
\text { Kemudian, akan disampaikan } \\
\text { secara umum pada saat KKG. } \\
\text { Catatan ini berupa perilaku atau } \\
\text { sikap siswa saat di sekolah. (b) } \\
\text { catatan tindak lanjut. Catatan ini } \\
\text { berisi pembinaan kepada siswa } \\
\text { yang mempunyai perbedaan } \\
\text { sikap. Catatan tindak lanjut } \\
\text { dibuat oleh guru dan } \\
\text { dikoordinasikan tidak ada } \\
\text { konselor. (c) catatan konseling } \\
\text { orang tua. Catatan ini } \\
\text { merupakan evaluasi tahap akhir } \\
\text { bagi siswa yang tetap } \\
\text { mengalami kekurangan dalam } \\
\text { bersikap dan tidak } \\
\text { perubahannya. Catatan ini akan } \\
\text { dikoordinasikan oleh guru dan } \\
\text { guru BK kepada wali murid } \\
\text { melalui kegiatan home visit } \\
\text { (dokumen lembar observasi } \\
\text { tahun 2017) }\end{array}$ \\
\hline
\end{tabular}

Sumber: Hasil wawancara dengan kepala sekolah dan waka kurikulum di SDI Roudlatul Jannah 29 Agustus 2017, dan SD Al-Hikmah tanggal 19 September 2017. 
E. Pembahasan

Perencanaan Pendidikan Karakter di SDI Raudlatul Jannah Sidoarjo dan SD Al-Hikmah Surabaya

Mengacu pada hasil penelitian yang sudah dipaparkan di atas menunjukkan bahwa, baik SDI Raudlatul Jannah Sidoarjo maupun SD Al-Hikmah Surabaya, keduanya sama-sama menyusun program pendidikan karakter dengan melakukan tahapan fungsi manajemen secara efektif. Keefektifan perencanaan tersebut terbukti dari adanya tahapan proses perencanaan yang dilakukan oleh sekolah dengan caramenyusun rencana strategis pendidikan karakter. Selain itu, penulis menyebutkan bahwa, secara umum,SDI Raudlatul Jannah Sidoarjo dan SD Al-Hikmah Surabayamampu melaksanakan perencanaan pendidikan karakter secara sistemik-integratif. Hal ini terbukti dari beberapa langkah perencanaan yang dilakukan, yaitu sebagai berikut:

1. Perencanaan dimulai dengan tujuan secara lengkap dan jelas dalam pertemuan dengan pihak pimpinan yayasan;

2. Adanya rumusan-rumusan tindakan yang akan dilakukan;

3. Analisis dan penetapan cara dan sarana untuk mencapai tujuan dalam kerangka melaksanakan perencanaan;

4. Penunjukan orang-orang yang bertanggungjawab dalam pelaksanaan termasuk juga ketua yayasan dalam mengadakan pengawasan; dan

5. Menentukan sistem yang memungkinkan pengukuran pencapaian berdasarkan kriteria tertentu.

Dari beberapa ungkapan-ungkapan di atas, peneliti memberikan kesimpulan bahwa, proses perencanaan merupakan suatu proses yang diakui dan perlu dijalani secara sistemik-integratif dan berurutan. Sebab, keteraturan merupakan proses rasional sebagai salah satu property pendidikan karakter. sesuai dengan teori George R. Terry yang menyebutkan bahwa, perencanaan merupakan aktivitas pengambilan keputusan mengenai apa yang akan dicapai, tindakan apa yangakan diambil dalam rangka pencapaian tujuan atau sasaran dan siapa yang akan melaksanakan tugas-tugasnya. 
Pengorganisasian Pendidikan Karakter di SDI Raudlatul Jannah Sidoarjo dan SD Al-Hikmah Surabaya

Dari data yang sudah dipaparkan dalam hasil penelitian menunjukan bahwa, manajemen pendidikan karakter, SDI Raudlatul Jannah Sidoarjo dan SD Al-ikmah Surabaya melakukan tahapan sesuai teori manajemen George R Terry, yang mengatakan bahwa dalam manajemen terdapat empat fungsi manajemen, yaitu perencanaan, pengorganisasian, pelaksanaan dan evaluasi (Abbas, 2012: 30). Selain itu, proses pengorganisasian di SDI Raudlatul Jannah Sidoarjo dan SD AlHikmah Surabaya juga sesuai dengan teori pengorganisasian menurut Hamalik yang telah disebutkan penelitian ini. Teori tersebut mengatakan bahwa, kegiatan pengorganisasian itu berupa pengelolaan ketenagaan, sarana prasarana, distribusi tugas dan tanggung jawab secara integral (Hamalik, 2006:81).

\section{Pelaksanaan Pendidikan Karakter di SDI Raudlatul Jannah Sidoarjo dan SD}

\section{Al-Hikmah Surabaya}

Pelaksanaan pendidikan karakter di SDI Raudlatul Jannah Sidoarjo dan SD Al-Hikmah Surabaya melibatkan kepala sekolah, guru kelas, guru mata pelajaran dan guru BK. Dalam fungsi pelaksanaan, kepala sekolah SDI Raudlatul Jannah Sidoarjo dan SD Al-Hikmah Surabaya lebihmenekankan pada upaya memotivasi dan mengarahkan para personil agardapat melaksanakan tugas pokok dan fungsinya masing-masing denganbaik.

Beberapa ungkapan dan hasil penelitian di atas, peneliti menyimpulkan bahwa pelaksanaan merupakan kegiatan untuk merealisasikan rencana menjadi tindakan nyata dalam rangka mencapai tujuan secara efektif, sehingga akan memiliki nilai. Kemudian, sebagai kepala sekolah, guru kelas, guru mata pelajaran dan guru BK yang berperan sebagai seorang manajer dalam menggerakkan bawahannya harus mempunyaicara atau trik tertentu, misalnya memberi motivasi dan usaha untuk membangkitkansemangat kerja bawahannya. Sebab, manajerial yang dibingkai dengan usaha membangkitkan semangat kerja bawahan akan mampu memberikan energi motivasi kepada bawahan secara signifikan. Pelaksanaan pendidikan karakter di SDI Raudlatul Jannah Sidoarjo dan SD AlHikmah Surabaya juga bisa dikatakan bahwa, pelaksanaan keduanya sesuai 
dengan teori pendidikan karakter Thomas Lickona. Dalam teori tersebut menyatakan bahwa, pendidikan karakter itu berupa moral knowing, moral feeling dan moral action (Lickona, 2015:595). Selain itu, sesuai juga dengan teori Zubaedi yang telah disebutkan oleh penelitian ini. Teori Zubaedi tersebut mengatakan bahwa, cara menanamkan pendidikan karakter itu dengan cara (1) mengintegrasikan butir-butir nilai pada semua mata pelajaran, (2) melalui kegiatan pembiasaan, (3) meningkatkan kerjasama antara pihak sekolah dengan orangtua (Zubaedi, 2011:14).

Hasil penelitian peneliti, baik dari wawancara, dokumentasi maupun observasi, kedua teori pendidikan karakter di atas tercermin pada pelaksanaan pendidikan karakter di SDI Raudlatul Jannah Sidoarjo dan SD Al-Hikmah Surabaya.

\section{Controlling/Evaluasi Pendidikan Karakter di SDI Raudlatul Jannah} Sidoarjo dan SD Al-Hikmah Surabaya

Berdasarkan paparan data pada hasil penelitian, menunjukan bahwa, pelaksanaan evaluasi pendidikan karakter di SDI Raudlatul Jannah Sidoarjo dan SD Al-Hikmah Surabaya dilakukan melalui manajemen partisipatif, artinya bahwa keberhasilan pendidikan karakter, bukan hanya menjadi tanggungjawab kepala sekolah, namun menjadi tanggungjawab semua warga sekolah. Sehingga, dalam evaluasi pendidikan karakter harus menilai karakter sekolah, fungsi staf sekolah sebagai pendidik karakter dan sejauh mana siswa memanifestasikan karakter yang baik. Hal ini sesuai dengan teori manajemen tentang pengawasan, yang menyebutkan bahwa secara umum tujuan pengawasan pendidikan karakter adalah mengembangkan dan meningkatkan kualitas program pendidikan karakter sesuai dengan perencanaan yang telah ditetapkan. Sehingga, dapat disimpulkan bahwa dalam evaluasi pendidikan karakter, SDI Raudlatul Jannah Sidoarjo dan SD AlHikmah Surabaya memanfaatkan teori manajemen pendidikan untuk mencapai tujuan program pendidikan karakter, mulai dari model perencanaan, pelaksanaan dan pengawasan pendidikan karakter dalam mencetak generasi yang berkarakter. Sehingga secara keseluruhan dapat dikatakan bahwa, Manajemen pendidikan karakter yang dilakukan di SDI Raudlatul Jannah Sidoarjo dan SD Al-Hikmah 
Surabaya sudah sesuai dengan teori manajemen, yakni dimulai dari tahapan perencanaan, pengorganisasian, pelaksanaan dan evaluasi.

Beberapa fungsi manajemen di atas, merupakan bukti bahwa, manajemen pendidikan karakter yang diterapkan oleh SDI Raudlatul Jannah Sidoarjo dan SD Al-Hikmah Surabaya sesuai dengan teori manajemen pendidikan yang diungkapkan oleh Pidarta. Teori Pidarta tersebut berbunyi bahwa, manajemen pendidikan merupakan aktivitas memadukan sumber-sumber pendidikan baik berupa tenaga, biaya, sarana prasarana dan informasi agar terpusat dan mudah dalam mencapai tujuan yang telah ditentukan (2004:36-37). Teori Pidarta di atas terbukti dengan adanya keterlibatan semua warga sekolah, baik guru, kepala sekolah, wakil kepala sekolah, orangtua bahkan CS dalam melaksanakan pendidikan karakter. Hal ini sesuai dengan hasil observasi dan wawancara peneliti pada saat peneliti melakukan penelitian tentang manajemen pendidikan karakter di SDI Raudlatul Jannah Sidoarjo dan SD Al-Hikmah Surabaya yang dilakukan pada bulan Juni hingga Oktober 2017

\section{F. Kesimpulan}

Implementasi pendidikan karakter di SDI Raudlatul Jannah Sidoarjo dan SD Al-Hikmah Surabaya adalah sebagai berikut:

\section{Tahap Perencanaan}

Keduanya menyusun program pendidikan karakter dengan melakukan tahapan fungsi manajemen secara efektif. Keefektifan perencanaan tersebut terbukti dari adanya tahapan proses perencanaan yang dilakukan oleh sekolah dengan cara menyusun rencana strategis pendidikan karakter. Selain itu, secara umum, SDI Raudlatul Jannah Sidoarjo dan SD Al-Hikmah Surabaya melaksanakan perencanaan pendidikan karakter secara sistemik-integratif.

\section{Tahap Pengorganisasian}

Pengorganisasian pendidikan karakter di SDI Raudlatul jannah Sidoarjo dan SD Al-Hikmah Surabaya dilakukan dengan cara mengkoordinasikan seluruh warga sekolah, yaitu kepala sekolah, waka kurikulum, guru kelas, guru mata pelajaran, BK, siswa bahkan cleaning service dalam mencapai tujuan pendidikan karakter. Hal ini terbukti dengan adanya pembagian-pembagian tugas pada 
masing-masing sumber daya manusia di sekolah. pada SDI Raudlatul Jannah Sidoarjo, pengorganisasian dilakukan dengan pembagian tugas pada koordinator jenjang, tim manajemen kurikulum, tim TPDS sekolah dan tugas guru dalam pelaksanaan pendidikan karakter.

\section{Tahap Pelaksanaan}

Pelaksanaan pendidikan karakter di SDI Raudlatul Jannah Sidoarjo dan SD Al-HIkmah Surabaya dengan melakukan pendekatan keteladanan (uswatun hasanah) dan pendekatan sistem. Pendekatan sistem tersebut meliputi kegiatan pembiasaan, yakni pembentukan atau pengembangan nilai-nilai karakter dengan cara pembiasaan dalam keseharian siswa di kelas, sekolah dan rumah, personifikasi, yakni peleburan nilai-nilai karakter dalam sikap dan perilaku seharihari.

\section{Tahap Evaluasi}

Evaluasi di SDI Raudlatul Jannah Sidoarjo menggunakan manajemen kontrol internal melalui buku pembiasaan, peraturan-peraturan sekolah dan rapor karakter, serta menggunakan manajemen eksternal melalui keterlibatan guru dalam mengontrol sikap dan perilaku peserta didik di sekolah dan orangtua dalam mengontrol sikap siswa di rumah melalui program home visit. Begitu juga di SD Al-Hikmah Surabaya.

\section{Daftar Pustaka}

Arikunto, Suharsimi. 2002. Penelitian Suatu Pendekatan Praktek. Jakarta: Rineka Cipta.

BNN. 2017. Angka Prelevansi Seks Pra-Nikah Menurut Provinsi Tahun 2017. Diakses pada 07/09/2018. bnn.go.id.

BPS. 2015. Kenakalan Remaja di Jawa Timur Tahun 2015. Diakses pada 07/09/2018. bps.go.id

Dalmetri. 2014. Pendidikan Untuk Pengembangan Karakter; Telaah Terhadap Gagasan Thomas Lickona dalam Educating for Character. Jurnal AlUlum. Vol.14(1) Juni. Hal 269-288.

Fahmi, Irham. 2014. Manajemen, Teori, Kasus dan Solusi. Bandung: Alfabeta.

Gunawan, H. 2012. Pendidikan Karakter; Konsep dan Implementasi. Bandung: Alfabeta.

Hadi, Amirul dan Haryono. 2008. Metodologi Penelitian Pendidikan. Bandung: Pustaka Setia.

Hamalik, Oemar. 2006. Manajemen Pengembangan Kurikulum. Bandung: Remaja Rosdakarya. 
Hidayat, Asep Saepul. 2012. Manajemen Sekolah Berbasis Karakter. Jurnal Inovasi dan Kewirausahaan. STIE Yasa Anggana Garut. Vol (1)1. Halaman 8-22.

Lickona, Thomas. 2012. Educating for Character; Mendidik untuk Membentuk Karakter. Jakarta: Bumi Aksara.

Moleong, Lexy J. 2000. Metode Penelitian Kualitatif. Bandung: Remaja Rosdakarya.

Mulyasa, E. 2011. Manajemen Berbasis Sekolah; Konsep Strategi dan Implementasi. Bandung: Remajarosdakarya.

----------. 2013. Manajemen Pendidikan Karakter. Jakarta: Bumi Aksara.

Muslich, Masnur. 2011. Pendidikan Karakter Menjawab Tantangan Krisis Multidimensional. Jakarta: Bumi Aksara.

Shofiah, Vivik dan Raudatussalamah. 2014. Self-Efficacy dan Self-Regulation Sebagai Unsur Penting dalam Pendidikan Karakter. Jurnal Penelitian Sosial dan Keagamaan. Vol.17(2) Juli-Desember. 